\title{
Fluorescence-based RT PCR Analysis: Determination of the Ratio of Soluble to Membrane-bound Forms of FcyRIIA Transcripts in Hematopoietic Cell Lines
}

\author{
M.A. Keller, ${ }^{1}$ D.L. Cassel, ${ }^{2}$ E.F. Rappaport, ${ }^{2}$ S.E. McKenzie, ${ }^{2}$ E. Schwartz, ${ }^{1,2}$ and S. Surrey ${ }^{1,2}$
}

\author{
${ }^{1}$ Molecular Biology Graduate Group, University of Pennsylvania School of Medicine, Philadelphia, Pennsylvania 19104; \\ ${ }^{2}$ Division of Hematology, The Children's Hospital of Philadelphia, Department of Pediatrics, The University of Pennsylvania \\ School of Medicine, Philadelphia, Pennsylvania 19104
}

We have developed a fluorescencebased RT PCR assay for determination of the ratio of two alternatively spliced transcripts in different cell types. Fluorescence detection, by an automated DNA sequencer, allows enhanced sensitivity and ease of data processing. PCR products are fluorescently tagged using a dye-labeled oligonucleotide primer during the PCR reaction. Assay conditions were first defined so that fluorescence intensity of the PCR products was linear with respect to input RNA and exponential relative to PCR cycle number. Sensitivity and reproducibility of detection were evaluated with serial dilutions of RT PCR reactions. We have applied this assay to an analysis of the lineage-specific expression of two human FcyRIIA transcripts, Fc $\gamma$ RIla1 and FoyRlla2, in different hematopoietic cell lines. Previously, we noted that when standard RT PCR conditions are used with primers that bracket the TM exon, the pattern of expression of these transcripts as assessed by ethidium bromide staining of agarose gels varied in different hematopoietic cell lineages. Using the fluorescence-based RT PCR method, we now confirm our previous findings and quantitate transcript ratios (FcyRIla2/FcyRIla1) in several hemapoietic cell lines. The ratio varies from 0.70 (41\% FcyRIla2) in the erythroleukemic cell line HEL, to 0.14 (12\% FcyRIIa2) in the monocytic cell line U937, to 0.07 (6\%
FcyRIIa2) in the multipotential cell line K562. This fluorescent RT PCR method provides a general approach to quantitating $\mathrm{mRNA}$ levels and ratios of PCR products in other gene systems.

D reaction (RT PCR) has been increasingly used for the study of gene expression. Its sensitivity allows assays to be performed rapidly with small amounts of input RNA without the use of radioactivity. Furthermore, the use of gene-specific primer pairs, a crucial factor when studying a member of a highly homologous gene family, affords a high degree of transcript specificity. Quantitation of specific transcripts is not trivial, because any assay involving PCR must address the limitations inherent in the amplification process. However, if reaction conditions are chosen such that amplification is exponential, and steps are taken to standardize the assay conditions, RT PCR can be a useful tool in studying transcript levels. The task is greatly simplified when a relative number, such as the ratio of two similar transcripts is sought, as opposed to an absolute number, such as viral copy number. The study of transcript ratios makes the need to control for the variability of reaction efficiency less crucial to the ultimate result, as factors influencing such parameters are likely to affect both transcripts equally. It also eliminates the need to control for variations in sample loading.

The method of detection of the PCR products is an important factor in quantitative PCR-based studies. Several different detection approaches have been employed. Radioactivity can be used directly in the PCR reaction, either in the form of a ${ }^{32} \mathrm{P}$-end-labeled primer, ${ }^{(1)}$ or with the addition of a $\left[\alpha^{-32} \mathrm{P}\right] \mathrm{dXTP},{ }^{(2)}$ both of which result in PCR products labeled with ${ }^{32} \mathrm{P}$. Alternatively, PCR products can be blotted and probed with a ${ }^{32}$ P-labeled probe. These methods are cumbersome, because they can involve either excision of bands from a gel followed by scintillation counting or quantitation by densitometric methods. Photon-counting cameras have also been used to quantitate radioactive signal intensity ${ }^{(3)}$; however, data processing is tedious. Ethidium bromide staining of gels can be used as a means of detection, although it involves time-consuming two-dimensional densitometry of negatives. $^{(4,5)}$ The use of fluorescent dyes in PCR is becoming more common, because of its versatility and sensitivity. ${ }^{(6,7)}$ The advent of instruments such as automated DNA sequencers ${ }^{(8)}$ with software to collect and analyze the laser-generated data has made fluorescence an attractive choice for detection and quantitative studies.

We are interested in studying the regulation of gene expression of the human Fc $\gamma$ RIIA gene. Fc $\gamma$ receptors bind the Fc portion of immunoglobulin $G$ and are involved in the regulation of immune 
response. They are expressed on the surface of many hematopoietic cells and, upon ligand binding, can cause phagocytosis, antibody-dependent cellular cytotoxicity, release of soluble mediators, or regulation of antibody production (for review, see reference 9). The human Fc $\gamma$ RIIA gene gives rise to multiple transcripts, as does the highly homologous FcyRIIB gene. ${ }^{(9)}$ Alternative splice-acceptor site usage in the $5^{\prime}$-untranslated region of Fc $\gamma$ RIIA gives rise to transcripts differing in their $5^{\prime}$ end. ${ }^{(10)}$ Alternative splicing of the transmembrane (TM) exon results in the production of two transcripts: Fc $\gamma$ RIIA1, containing the TM exon, and FcyRIIA2, lacking the TM exon. ${ }^{(11,12)}$ A protein of the appropriate size predicted by the Fc $\gamma$ RIIA2 transcript can be immunoprecipitated from the medium of cells making this transcript. ${ }^{(11)}$ This soluble receptor may play an important role in the regulation of immune function by acting as a negative regulator of its integral membrane counterpart, ${ }^{(13,14)}$ as is the case with other soluble receptors, such as GM-CSF $\mathrm{R}^{(15)}$ IL-4 $\mathrm{R}_{,}{ }^{(16)}$ and IL-7 R. ${ }^{(17)}$ Our previous study of the differential expression of the Fc $\gamma$ RII transcripts in hematopoietic cell lineages using RT PCR suggested that expression of the Fc $\gamma$ RIIA transcripts may be regulated in a lineage-specific manner. ${ }^{(18)}$ However, the RT PCR assay employed in those studies was not quantitative. In this report we define conditions for a fluorescence-based RT PCR assay and apply this assay to quantitative determination of the ratio of soluble to membrane forms of the Fc $\gamma$ RIIA transcripts. This method is also applicable to other PCR-based studies of gene expression.

\section{MATERIALS AND METHODS}

\section{Cell Lines}

The human erythroleukemic cell line HEL (ATCC TIB 180), the human monocytic cell line U937 (ATCC CRL 1593), and the human multipotential hematopoietic cell line K562 (ATCC CCL 243) were obtained from American Type Culture Collection (Rockville, MD) and were maintained in serum-free macrophage medium with $2 \mathrm{mM} \mathrm{L-glutamine}$ and $100 \mathrm{U} / \mathrm{ml}$ each of penicillin and streptomycin, all obtained from GIBCO BRL (Gaithersburg, MD). HEL cells are bipotential (erythroid and megakaryo- cytic; see reference 19); they were used in this study as a model of megakaryocyte gene expression.

\section{RNA Extraction}

Cells were harvested, total RNA was isolated using RNAzol (Tel-test, Inc., Friendswood, TX), and RNA was then resuspended in diethylpyrocarbonate-treated water, and frozen at $-70^{\circ} \mathrm{C}$ in small aliquots. RNA concentration was determined spectrophotometrically, and RNA quality was assessed by electrophoresis on a nondenaturing $1 \%(\mathrm{wt} / \mathrm{vol})$ agarose gel in $10 \mathrm{~mm}$ sodium phosphate (pH 7.4) containing ethidium bromide.

\section{Creation of Positive Control Template}

We created a control template that competes for amplification by the same primers and results in a PCR product of a size distinguishable from the cDNA-derived PCR products. This was accomplished by first using chimeric primers in a PCR reaction to add FcyRIIA sequences onto the ends of an unrelated DNA fragment. Chimeric primers were made with $5^{\prime}$ ends containing sequences from the human FcyRIIA gene followed by $3^{\prime}$ sequences from the luciferase cDNA. ${ }^{(20)}$ The $5^{\prime}$-chimeric primer $\left(5^{\prime}\right.$-ATGTCTCAGAATGTATGTCCCAGAGATCTA GCTCATTCC-3') and $3^{\prime}$-chimeric primer (5'-CTCAAATTGGGCAGCCTTCACGTTTTAGAATCCATG-3') were used in a PCR reaction with the $\mathrm{pXP1}$ vector containing the luciferase cDNA, kindly provided by S.K. Nordeen (University of Colorado Health Sciences Center, Denver). The resulting PCR product was blunt-ended using Klenow fragment (GIBCO BRL, Gaithersburg, MD) and then subcloned into the SmaI site of pGEM3Z (Promega, Madison, WI). The control plasmid was added to the PCR mix, and an aliquot of the PCR mix was added to each PCR reaction tube. Fc $\gamma$ RIIA primers complementary to the Fc $\gamma$ RIIA sequences of the chimeric primers were used to amplify the insert, resulting in a PCR product 550 bp in length, whereas the PCR products derived from the Fc $\gamma$ RIIA cDNAs were 639 and $763 \mathrm{bp}$. The amount of control plasmid included in each competitive PCR reaction was $15 \mathrm{pg}$, which resulted in similar fluorescence intensities for control and cDNA-derived PCR products.

\section{cDNA Synthesis}

An RT mix was created by combining $5 \times$ RT buffer (250 mM Tris- $\mathrm{HCl}$ at $\mathrm{pH} 8.3,75$ $\mathrm{mM} \mathrm{KCl}, 3 \mathrm{~mm} \mathrm{MgCl}_{2}$ ), DTT, random primers (Promega, Madison, WI), and dNTPs (Pharmacia, Piscataway, NJ). An aliquot of this mix was added to total RNA with or without yeast tRNA (Sigma, St. Louis, MO), followed by the addition of 500 units of Moloney murine leukemia virus (M-MLV) RT (GIBCO BRL, Gaithersburg, MD). The final concentrations in $20 \mu \mathrm{l}$ are as follows: $50 \mathrm{~mm}$ Tris$\mathrm{HCl}$ (pH 8.3); $3 \mathrm{~mm} \mathrm{MgCl}$; $10 \mathrm{~mm}$ DTT; $1.3 \mu \mathrm{M}$ random primers; and $500 \mu \mathrm{M}$ each dATP, dCTP, dGTP, and TTP. In the experiments testing input RNA amounts (Fig. 1), the final RNA quantities in each reaction were adjusted with yeast tRNA, so that total nucleic acid amounts were constant. Similar experiments were done without the addition of tRNA with similar results (data not shown). The range of total RNA tested varied from 0.5 to $30 \mu \mathrm{g}$. The reaction was incubated for $10 \mathrm{~min}$ at $25^{\circ} \mathrm{C}$, followed by $60 \mathrm{~min}$ at $42^{\circ} \mathrm{C}$, and then terminated by incubation for 10 $\min$ at $90^{\circ} \mathrm{C}$, followed by the addition of $20 \mu \mathrm{l}$ of $1 \times \mathrm{RT}$ buffer, bringing the total volume to $40 \mu \mathrm{l}$. The PCR reactions and resulting data points are referred to by the initial amount of total cell line RNA in the $\mathrm{RT}$ reaction, although only a fraction of the RT reactions are used in the PCR reactions.

\section{Oligonucleotide Primers and PCR}

The primers used to specifically amplify the Fc $\gamma$ RIIA transcripts have been described elsewhere. ${ }^{(18)}$ The Fc $\gamma$ RIIA-specific $5^{\prime}$ primer (5'-ATGTCTCAGAAT GTATGTCCCAGA-3') was synthesized by the Nucleic Acid/Protein Core facility at the Children's Hospital of Philadelphia, and the dye-tagged 3' primer containing a fluorescein dye attached to the $5^{\prime}$ end (5'-F CTCAAATTGGGCAGCCTTCAC-3', where $\mathrm{F}$ represents the fluorescein residue) was commercially synthesized by Research Genetics, Inc. (Huntsville, AL). PCR mix was created by combining $10 \times$ PCR buffer $[100 \mathrm{~mm}$ Tris- $\mathrm{HCl}$ at $\mathrm{pH} 8.3$, $500 \mathrm{~mm} \mathrm{KCl}, 15 \mathrm{~mm} \mathrm{MgCl}_{2}, 0.01 \%$ (wt/ vol) gelatin], dNTPs, $5^{\prime}$ primer, $3^{\prime}$ primer, and control template (15 pg per reaction). For the PCR reaction, $12 \mu \mathrm{l}$ of the RT reaction described above was combined with $86 \mu \mathrm{l}$ of the PCR mix. 
A

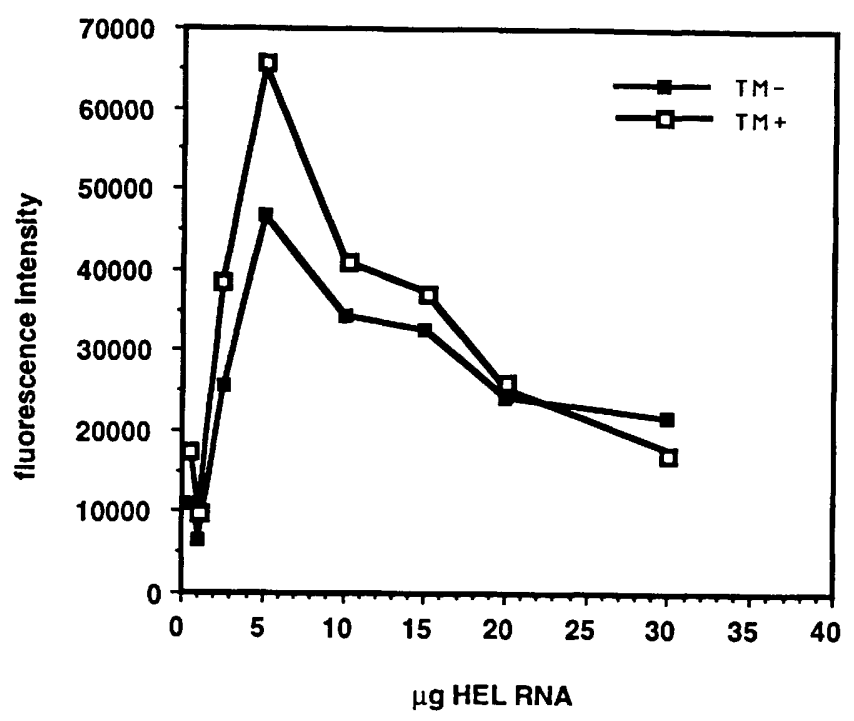

B

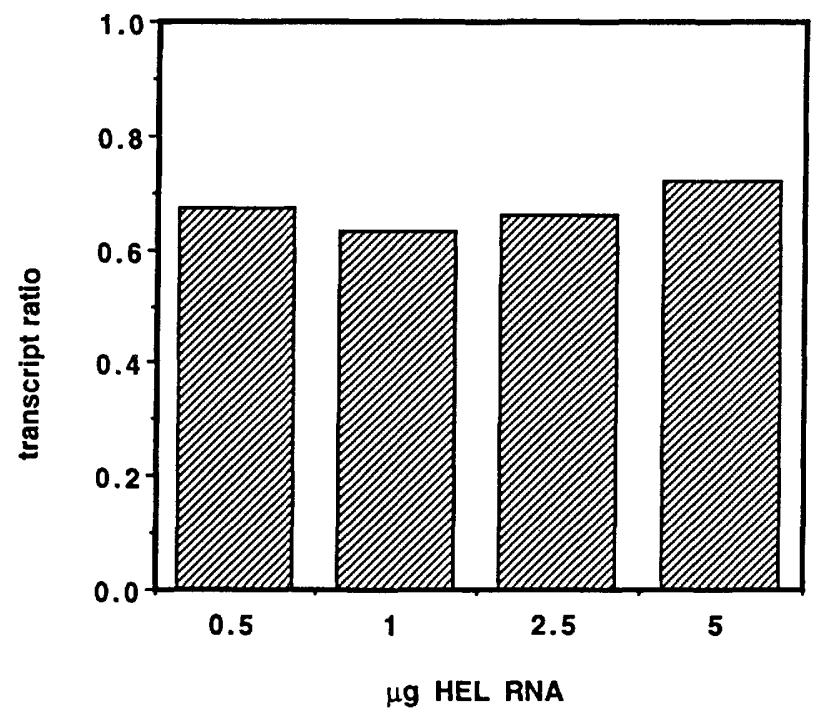

C

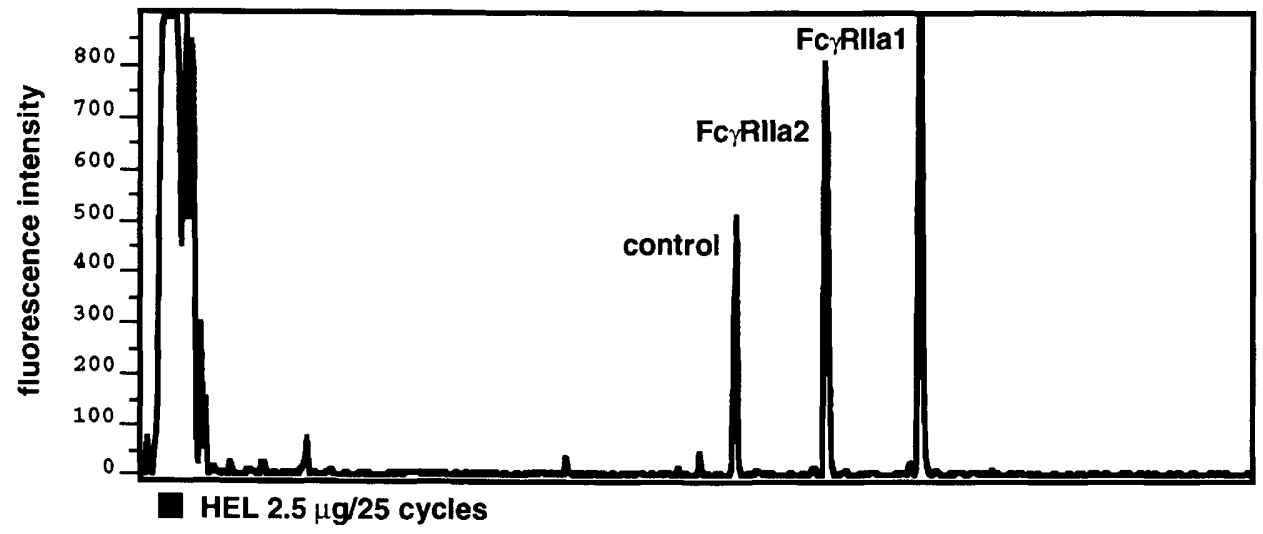

FICURE 1 Fluorescence intensity of RT PCR products as a function of input RNA HEL cell total RNA ranging from 0.5 to $30 \mu \mathrm{g}$ with a final nucleic acid content of $30 \mu \mathrm{g}$ (adjusted with yeast tRNA) was used for RT PCR with 25 cycles of amplification. Aliquots of each reaction were run on a $5 \%$ (wt/vol) polyacrylamide gel using an automated DNA sequence analyzer and evaluated with the Gene Scanner 1.1 software. A representative experiment is shown. The equation of the line created by the data points is shown as well as the standard errors, represented by the vertical lines at each data point. (A) Fluorescence intensity as a function of input RNA; $(B)$ Fc $\gamma$ RIIa2/Fc $\gamma$ RIIa1 (TM $-/$ TM + ) transcript ratios as a function of input RNA for the range $0.5-5.0 \mu \mathrm{g}$. $(C)$ A representative chromatogram of $2.5 \mu \mathrm{g}$ of HEL cell total RNA is shown with the peaks of the internal control, Fc $\gamma$ RIIA2, and FC $\gamma$ RIIA1.

Samples were placed in the Perkin-Elmer Cetus 9600 PCR machine and heated to $94^{\circ} \mathrm{C}$ for at least $5 \mathrm{~min}$, as a hot start ${ }^{(21)}$ to decrease nonspecific annealing. Two and one-half units of Amplitaq (PerkinElmer Cetus, Norwalk, CT) were then added, bringing the final volume to 100 $\mu \mathrm{l}$. The final concentrations were as follows: $50 \mathrm{~mm} \mathrm{KCl} ; 10 \mathrm{~mm}$ Tris- $\mathrm{HCl}(\mathrm{pH}$ 8.3); $1.5 \mathrm{mM} \mathrm{MgCl}_{2} ; 0.001 \%$ (wt/vol) gelatin; 30 pmoles of $5^{\prime}$ primer; and 30 pmoles of $3^{\prime}$ primer. The PCR reaction consisted of denaturation at $94^{\circ} \mathrm{C}$ for 30 sec, annealing at $64^{\circ} \mathrm{C}$ for $30 \mathrm{sec}$, and extension at $72^{\circ} \mathrm{C}$ for $60 \mathrm{sec}$ for the number of cycles indicated. Expected sizes of PCR products are 762 bp for Fc $\gamma$ RIIa1, $639 \mathrm{bp}$ for Fc $\gamma$ RIla2, and 550 bp for the internal control.

\section{Detection}

Ten microliters of the PCR reactions was loaded on a $1.5 \%(\mathrm{wt} / \mathrm{vol})$ agarose gel in $1 \times$ TBE buffer and run at $150 \mathrm{~V}$ for $\sim 30$ min to assess whether RT PCR had occurred. One microliter of each PCR reaction or $1 \mu$ l of serial dilutions in PCR mix were mixed with an equal volume of deionized formamide, heated at $95^{\circ} \mathrm{C}$ for $2 \mathrm{~min}$, and placed on ice. Samples were run on a $5 \%(\mathrm{wt} / \mathrm{vol})$ polyacrylamide gel containing $8 \mathrm{M}$ urea on the automated DNA Sequencer 373A (Applied Biosystems, Inc., Foster City, CA). Genescan 2500 markers (Applied Biosystems, Inc.) were included in each sample or representative samples. Electrophoresis was performed for $12 \mathrm{hr}$ at $30 \mathrm{~W}$ with a photomultiplier setting of $580 \mathrm{mV}$, and data were collected and analyzed using the Gene Scanner software GS Analysis 1.1. The ratios were calculated using peak areas, and data were further analyzed using Cricket Graph (Cricket Software, Malvern, PA) on a Macintosh IIci computer (Apple Computer, Inc., Cupertino, CA). 


\section{RESULTS}

\section{Assay Standardization}

Total HEL cellular RNA of varying amounts was used in RT PCR reactions, to determine the range over which fluorescence intensity was linear with respect to input RNA. When the PCR cycle number was held constant at 25 , there was a linear relationship between fluorescence intensity and input HEL RNA between 0.5 and $5.0 \mu \mathrm{g}$ (Fig. 1A), with linear regression coefficients of $r^{2}=$ 0.979 for Fc $\gamma$ RIIa1 and $r^{2}=0.986$ for Fc $\gamma$ RIIa2, indicating that fluorescence is directly proportional to input RNA in this range. In addition, relative transcript ratios (Fc $\gamma$ RIIa2/Fc $\gamma$ RIIa1) remained constant $(0.65)$ over this linear response range (Fig. 1B). Thus, these data establish that $<5 \mu \mathrm{g}$ of input RNA is optimal for ratio quantitation. Two and one-half micrograms of input RNA was therefore chosen for monitoring relative transcript ratios in the different hematopoietic lineages. It is interesting to note that at higher input RNA (i.e., 10$30 \mu \mathrm{g}$ ), the output fluorescence intensity decreases.

Because we were interested in determining ratios and not absolute transcript numbers, fluorescence output of an internal control was not required; however, an internal control was included in each reaction to assess efficiency and variability of PCR. The con- trol was an unrelated plasmid insert containing sequences at the ends that hybridize to the Fc $\gamma$ RIIA primers and, therefore, a competed with first-strand RT -derived CDNA for the primer pair.

To determine the optimal PCR cycle number, a constant amount of input RNA $(2.5 \mu \mathrm{g})$ and control plasmid (15 pg) were used in RT PCR reactions, and the cycle number was varied between 24 and 40. Our results show exponential increases in fluorescence intensity between 24 and 28 cycles of PCR (Fig. 2A) fitting an exponential equation with $r^{2}=0.992$ for Fc $\gamma$ RIIa1 and $r^{2}=0.987$ for Fc $\gamma$ RIIa2. When graphed as log fluorescence intensity versus cycle number, the results show a linear relationship at these cycle numbers for the internal control as well as the two Fc $\gamma$ RIIA mRNAs, followed eventually by a plateau. When transcript ratio was plotted versus cycle numbers at which fluorescence is exponential, the ratio remained close to 0.70 (Fig. 2B). Thus, for further experiments, 25 cycles of amplification were chosen, because fluorescence intensity varied exponentially with respect to cycle number in this range.

The sensitivity and accuracy of the assay were tested by analyzing serial dilutions of RT PCR reactions. The results of five separate experiments show that the scanner accurately detects fluorescence intensity over a fourfold dilution range $(0.25-1.0)$, resulting in similar ratios of
Fc $\gamma$ RIIa2/Fc $\gamma$ RIIa1 transcripts over this range (Fig. 3). The photomultiplier within the automated DNA sequencer can also be adjusted to increase the range of detection (data not shown).

\section{Application of Assay to Quantify mRNA Ratios of Soluble/Membrane FcyRIIA in Different Hematopoietic Lineages}

RNA samples from HEL (megakaryocytic), K562 (multipotential), and U937 (monocytic) hematopoietic cell lines were then evaluated using the conditions described above to determine transcript ratios of soluble to membranebound forms of Fc $\gamma$ RIIA. HEL cells consistently showed a 10 -fold greater relative expression $(0.70 \pm 0.09)$ of soluble/ membrane transcripts compared with K562 cells $(0.07 \pm 0.02)$, whereas U937 cells $(0.14 \pm 0.03)$ expressed twice the ratio of K562 cells (Fig. 4).

\section{DISCUSSION}

We have developed a fluorescence-based RT PCR assay for accurate determination of relative mRNA ratios of soluble/membrane-bound forms of Fc $\gamma$ RIIA transcripts in different hematopoietic cell types. RT PCR is a powerful technique due to its sensitivity and specificity. We have determined conditions under
A

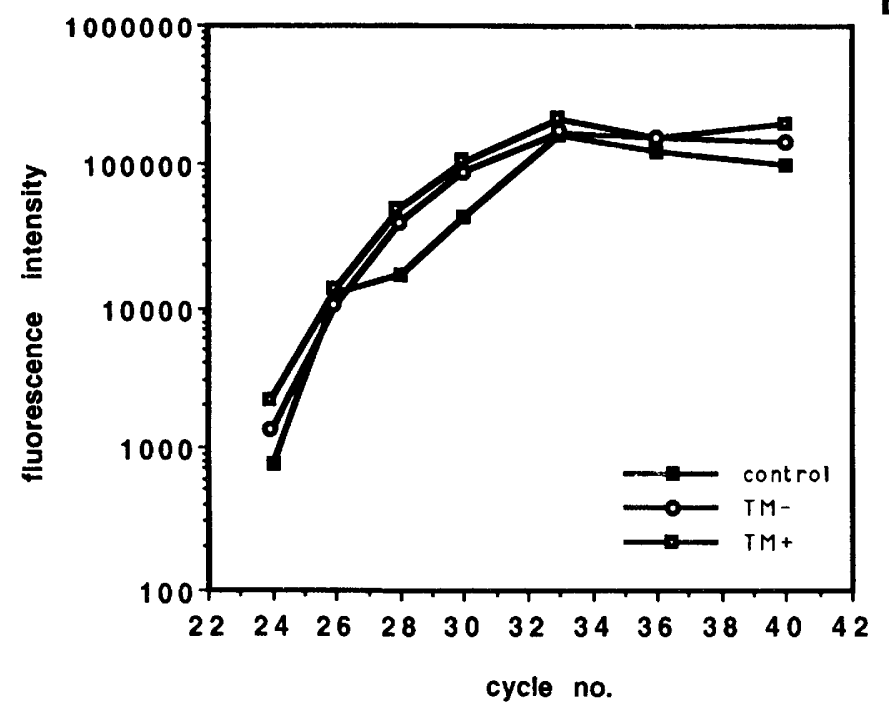

B

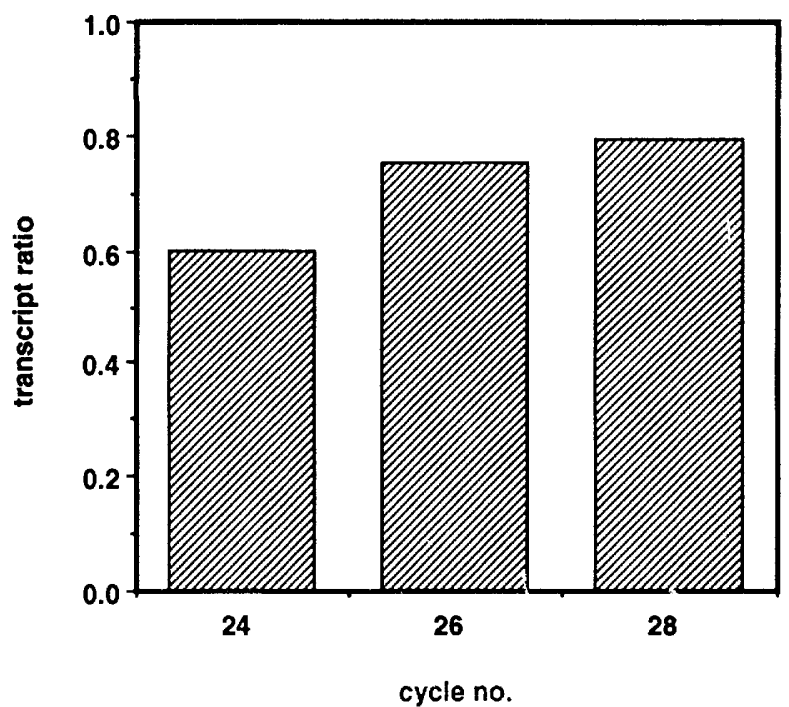

FIGURE 2 Fluorescence intensity as a function of PCR cycle number. HEL cell total RNA ( $2.5 \mu \mathrm{g})$ was used in an RT PCR experiment in which the cycle number varied from 24 to 40 , and aliquots were run and analyzed as in Fig. 1. $(A)$ Log of fluorescence intensity as a function of cycle number; (B) Fc $\gamma \mathrm{RIIa} 2 / \mathrm{Fc} \gamma \mathrm{RIIa} 1 \mathrm{TM}-/ \mathrm{TM}+)$ transcript ratios as a function of cycle number in the exponential range of fluorescence response between 24 and 28 cycles. 


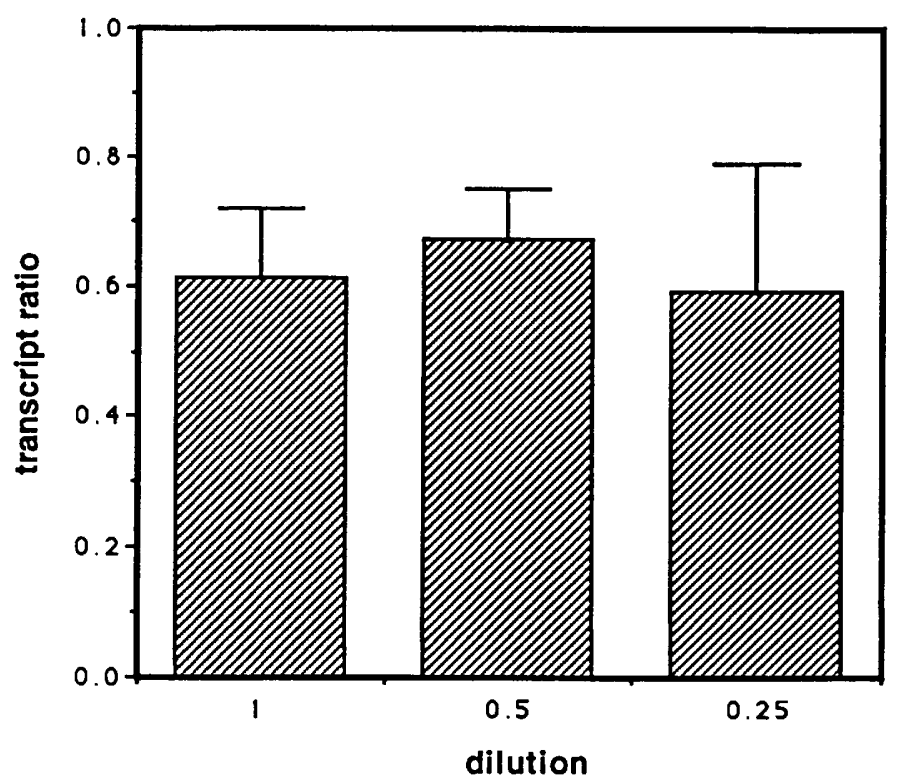

FIGURE 3 Ratio of Fc $\gamma$ RIIa2/Fc $\gamma$ RIIa1 $(\mathrm{TM}-/ \mathrm{TM}+$ ) as a function of reaction dilution. Five micrograms of HEL cell total RNA was used in an RT PCR experiment with 25 cycles of PCR amplification, aliquots were removed, serial dilutions were made, and samples were run and analyzed as in Fig. 1. Fc $\gamma$ RIIa2/Fc $\gamma$ RIIa1 $(\mathrm{TM}-/ \mathrm{TM}+)$ transcript ratio as a function of dilution is presented as the average \pm the standard deviation from five independent experiments.

which RT PCR gives an accurate reflection of the ratios of the transcripts of interest. When performing RT PCR in the hopes of drawing conclusions about alternatively spliced transcript ratios, the initial reaction producing cDNA from RNA must first be optimized such that the cDNA pool produced is representative of the mRNA(s) of interest. Complementary DNA can be made from total RNA with one of three types of primers: oligo(dT), gene-specific primers, or ran- dom hexamers. Random hexamers were used in this study to prime the cDNA synthesis such that the CDNA population is most likely to be a reasonably accurate representation of the message population and free of primer bias.

Several PCR parameters must be controlled when quantitating ratios of PCR products (for review, see reference 22). The amplification must be studied in the linear range, where the ratio of transcripts after amplification is directly pro-

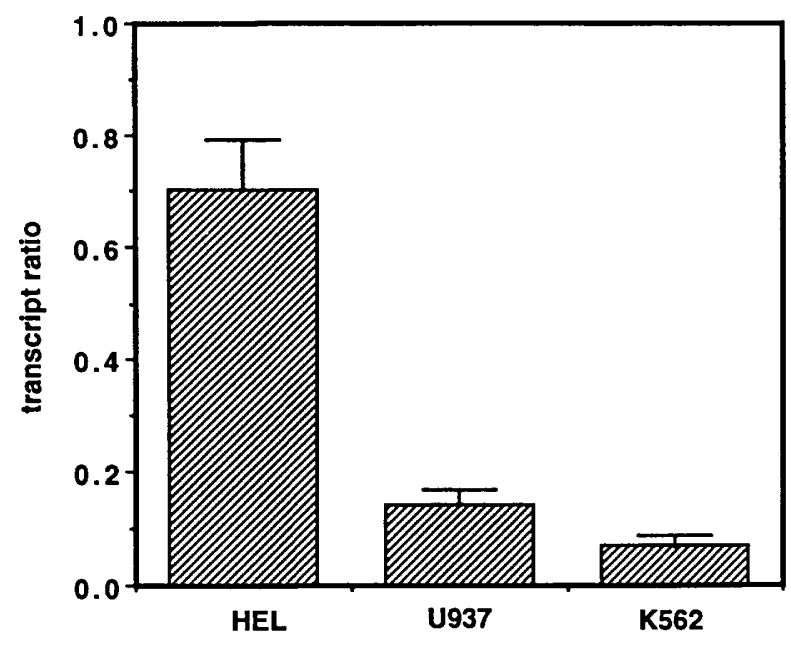

FIGURE 4 Ratio of Fc $\gamma$ RIIa2/Fc $\gamma$ RIIa1 (TM $-/ T M+)$ transcripts in different cell lines as measured by fluorescence-based RT PCR. Total RNAs $(2.5 \mu \mathrm{g})$ from HEL, U937, and K562 cells were subjected to fluorescence-based RT PCR for 25 cycles of amplification, and aliquots were run and analyzed as in Fig. 1. Fc $\gamma$ RIIa2/Fc $\gamma$ RIIa1 $(\mathrm{TM}-/ \mathrm{TM}+)$ transcript ratio is presented as the average \pm the standard deviation for three to five independent experiments for each cell line.

portional to that before amplification. This is dependent both on the quantity of input template ${ }^{(23)}$ and the extent of PCR amplification. To address these points in our study, the appropriate quantity of input template and cycle number was determined by keeping one variable constant while varying the other. An amount of input RNA and cycle number that were in the linear range of amplification and gave a detectable signal were used in further experiments. We observed a decrease in fluorescence intensity with higher amounts of input RNA (10-30 $\mu \mathrm{g})$; a similar phenomenon was seen previously by Williams et al., using ethidium bromide detection and radioactive quantitation. ${ }^{(23)}$ It has become common to employ an internal standard when attempting to quantitate PCR products. In our study, however, when the relative ratio of PCR products is sought, the need for an internal control is lessened. We chose to include a competitive internal control simply to monitor the PCR reactions; the fluorescence intensity of the control product was not used in the calculations of the transcript ratios.

Our RT PCR method, using a dyetagged primer and an automated DNA sequencer, is significantly more sensitive than methods based on ethidium bromide staining of gels. Because only one of the PCR primers is tagged with a fluorescent dye at the $5^{\prime}$ end, the number of fluorescent molecules is directly proportional to the number of PCR products present. This is in contrast to ethidium bromide, which intercalates DNA, so that larger DNA fragments contain more bound ethidium bromide, thus entailing additional corrections for fragment size. The fluorescent PCR fragments can be resolved on agarose or polyacrylamide gels in a fluorescent fragment analyzer that uses a laser to scan the gel and records the intensity of the bands as peaks in a chromatogram (see Fig. 1C). A similar method has been used to study the expression of the bcr-abl gene. ${ }^{(11)}$ It is particularly useful for the study of alternatively spliced transcripts from a gene family like the Fc $\gamma$ RII family or transcripts from different but highly homologous genes, because the specificity of RT PCR is paired with the sensitivity of fluorescence.

It is clear that the delineation of the precise mechanisms of lineage-specific alternative splicing will be important to 
understand the complexities of gene regulation. The quantitative assay developed here has allowed us to evaluate the transcript ratios for soluble/membranebound forms of Fc $\gamma$ RIIA and to determine that expression of the Fc $\gamma$ RIIA gene is regulated in a lineage-specific manner. This fluorescence-based method will now be used to delineate the cis-acting elements involved in this regulation in an attempt to better understand alternative splicing in general and FcyRIIA expression in particular.

In this study we have developed a quantitative assay that facilitates the measurement of relative transcript ratios in different lineages. This methodology can now be used in studies examining the regulated expression of these transcripts. Quantitation of PCR products has been used for monitoring minimal residual disease, ${ }^{(24,25)}$ gene dosage, ${ }^{(4,26)}$ viral copy number, ${ }^{(27)}$ and for studies of multiple transcript isoforms. ${ }^{(28)}$ The fluorescence-based RT PCR method described above is both sensitive and reproducible. Using defined conditions, the ratios after amplification should reflect the ratio of the transcripts present in the input RNA. Conditions have been defined to attach fluorophores to the 5' end of primers either during ${ }^{(29)}$ or af$\operatorname{ter}^{(30)}$ oligonucleotide synthesis. Fluorescein-12-dUTP can also be incorporated during the PCR reaction to tag PCR products. ${ }^{(31)}$ Fluorescent dyes such as thiazole orange (TOTO) can also be reacted with PCR products after amplification as a means of detection and quantitation. ${ }^{(32)}$ One limitation to the use of any of these fluorescence detection methods is the cost of the equipment and software needed to process the data. However, these sequencers are becoming more common, and less expensive fluorescence detection devices may be developed so that the cost of the scanning equipment will not be the limiting factor. Fluorescence-based PCR methodology should be applicable to PCR product quantitation studies as well as RT PCR analyses involving multiple transcript isoforms. The use of fluorescence in PCR adds flexibility and sensitivity to the continually increasing body of PCR applications.

\section{ACKNOWLEDGMENTS}

We thank Paolo Fortina for helpful discussions and comments. This work was supported by National Institutes of Health grants RO1 DK 16691, P30 HD28815, and PO1 HL 40387.

\section{REFERENCES}

1. Owczarek, C.M., P. Enriquez-Harris, and N.J. Proudfoot. 1992. The primary transcription unit of the human $\alpha 2$ globin gene defined by quantitative RT/PCR. $\mathrm{Nu}$ cleic Acids Res. 20: 851-858.

2. Wiesner, R.J. 1992. Direct quantification of picomolar concentrations of mRNAs by mathematical analysis of reverse transcription/exponential polymerase chain reaction assay. Nucleic Acids Res. 20: 5863-5864.

3. Nakayama, H., H. Yokoi, and J. Fujita. 1992. Quantification of mRNA by nonradioactive RT-PCR and CCD imaging system. Nucleic Acids Res. 20: 4939.

4. Abbs, S. and M. Bobrow. 1992. Analysis of quantitative PCR for the diagnosis of deletion and duplication carriers in the dystrophin gene. J. Med. Genet. 29: 191-196.

5. Bonini, J.A. and C. Hofmann. 1991. A rapid, accurate, nonradioactive method for quantitating RNA on agarose gels. BioTechniques 11: 708-709.

6. Pieretti, M., F. Zhang, Y.-H. Fu, S.T. Warren, B.A. Oostra, C.T. Caskey, and D.L. Nelson. 1991. Absence of expression of the FMR-1 gene in fragile $X$ syndrome. Cell 66: 817-822.

7. Porcher, C., M.-C. Malinge, C. Picat, and B. Grandchamp. 1992. A simplified method for determination of specific DNA or RNA copy number using quantitative PCR and an automatic DNA sequencer. BioTechniques 13: 106-13.

8. Connell, C., S. Fung, C. Heiner, J. Bridgham, V. Chakerian, E. Heron, B. Jones, S. Menchen, W. Mordan, M. Raff, M. Recknor, L. Smith, J. Springer, S. Woo, and M. Hunkapiller. 1987. Automated DNA sequence analysis. BioTechniques 5: 342-348.

9. Ravetch, J.V. and J.-P. Kinet. 1991. Fc Receptors. Annu. Rev. Immunol. 9: 457-492.

10. McKenzie, S.E., M.A. Keller, D.L. Cassel, A.D. Schreiber, E. Schwartz, S. Surrey, and E.F. Rappaport. 1992. Characterization of the $5^{\prime}$ flanking transcriptional regulatory region of the human Fcy receptor gene, FC $\gamma$ RIIA. Mol. Immunol. 29: 1165-1174.

11. Rappaport, E.F., D.L. Cassel, D.O. Walterhouse, S.E. McKenzie, S. Surrey, M.A. Keller, A.D. Schreiber, and E. Schwartz. 1993. A soluble form of the human Fc receptor Fc $\gamma$ RIIA: Cloning, transcript analysis and detection. Exp. Hematol. 21: 689696.

12. Warmerdam, P.A.M., J.G. van de Winkel, E.J. Gosselin, and P.J.A. Capel. 1990. Molecular basis for a polymorphism of human Fc $\gamma$ RII (CD32). J. Exp. Med. 172: 19-
25.

13. Ierino, F.L., M.S. Powell, I.F.C. McKenzie, and P.M. Hogarth. 1992. Functional recombinant soluble human Fc $\gamma$ RII. Transplant. Proc. 24: 2326-2327.

14. Sautes, C., C. Teillaud, N. Mazieres, E. Tartour, C. Bouchard, A. Galinha, M. Jourdes, R. Spagnoli, and W.-H. Fridman. 1992. Soluble Fc $\gamma \mathrm{R}(\mathrm{sFc} \gamma \mathrm{R})$ : Detection in biological fluids and production of a murine recombinant $\mathrm{sF} c \gamma \mathrm{R}$ biologically active in vitro and in vivo. Immunobiology 185: 207-221.

15. Raines, M.A., L. Liu, S.G. Quan, V. Joe, J.F. DiPersio, and D.W. Golde. 1991. Identification and molecular cloning of a soluble human granulocyte-macrophage colonystimulating factor receptor. Proc. Natl. Acad. Sci. 88: 8203-8207.

16. Mosley, B., M.P. Beckman, C.J. March, R.L. Idzerda, S.D. Gimpel, T. VandenBos, D. Friend, A. Alper, D. Anderson, J. Jackson, J.M. Wignall, C. Smith, B. Gallis, J.E. Sims, D. Urdal, M.B. Widmer, D. Cosman, and L.S. Park. 1989. The murine interleukin-4 receptor: Molecular cloning and characterization of secreted and membrane bound forms. Cell 59: 335-348.

17. Goodwin, R.G., D. Friend, S.F. Ziegler, R. Jerzy, B.A. Falk, S. Gimpel, D.Cosman, S. Dower, C.J. March, A.E. Namen, and L.S. Park. 1990. Cloning of the human and murine interleukin-7 receptors: Demonstration of a soluble form and homology to a new receptor superfamily. Cell 60: 941-951.

18. Cassel, D.L., M. Keller, S. Surrey, E. Schwartz, A.D. Schreiber, E.F. Rappaport, and S.E. McKenzie. 1993. Differential expression of Fc $\gamma$ RIIA, Fc $\gamma$ RIIB, Fc $\gamma$ RIIC in hematopoietic cells: Analysis of transcripts. Mol. Immunol. 30: 451-460.

19. Tabilio, A., J.-P. Rosa, U. Testa, N. Kieffer, A.T. Nurden, M.C. Del Canizo, J. BretonGorius, and W. Vainchenker. 1984. Expression of platelet membrane glycoproteins and $\alpha$-granule proteins by a human erythroleukemia cell line (HEL). EMBO J. 3: 453-459.

20. de Wet, J.R., K.V. Wood, M. DeLuca, D.R. Helinski, and S. Subramani. 1987. Firefly luciferase gene: Structure and expression in mammalian cells. Mol. Cell. Biol. 7: 725-737.

21. Mullis, K.B. 1991. The polymerase chain reaction in an anemic mode: How to avoid cold oligodeoxyribonuclear fusion. PCR Methods Applic. 1: 1-4.

22. Ferre, F. 1992. Quantitative or semi-quantitative PCR: Reality versus myth. $P C R$ Methods Applic. 2: 1-9.

23. Williams, W.V., H. Rosenbaum, and D.B. Weiner. 1992. Effect of RNA concentration on cDNA synthesis for DNA amplification. PCR Methods Applic. 2: 86-88.

24. Noonan, K.E., C. Beck, T.A. Holzmayer, J.E. Chin, J. S. Wunder, I.L. Andrulis, A.F. 
Gazdar, C.L. Willman, B. Griffith, D.D. Von Hoff, and I.B. Roninson. 1990. Quantitative analysis of MDR1 (multidrug resistance) gene expression in human tumors by polymerase chain reaction. Proc. Natl. Acad. Sci. 87: 7160-7164.

25. Billadeau, D., M. Blackstadt, P. Greipp, R.A. Kyle, M.M. Oken, N. Kay, and B. Van Ness. 1991. Analysis of B-lymphoid malignancies using allele-specific polymerase chain reaction: A technique for sequential quantitation of residual disease. Blood 78: 3021-3029.

26. Lubin, M.B., J.D. Elashoff, S.-J. Wang, J.I. Rotter, and H. Toyoda. 1991. Precise gene dosage determination by polymerase chain reaction: Theory, methodology and statistical approach. Mol. Cell. Probes 40: 307-317.

27. Holodniy, M.D., A. Katzenstein, D.M. Israelski, and T.C. Merigan. 1991. Reduction in plasma human immunodeficiency virus ribonucleic acid after dideoxynucleoside therapy as determined by polymerase chain reaction. J. Clin. Invest. 88: 1755-1759.

28. Buck, K.J., R.A. Harris, and J.M. Sikela. 1991. A general method for quantitative PCR analysis of mRNA levels for members of gene families: Application to $\mathrm{GABA}_{\mathrm{A}}$ receptor subunits. BioTechniques 11: 636641.

29. Theisen, P., C. McCollum, K. Upadhya, K. Jacobson, H. Vu, and A. Andrus. 1992. Fluorescent dye-phosphoramidite labelling of oligonucleotides. Tetrahedron Lett. 33: 5033.

30. Smith, L.M., S. Fung, M.W. Hunkapiller, T.J. Hunkapiller, and L.E. Hood. 1985. The synthesis of oligonucleotides containing an aliphatic amino group at the 5 'terminus: Synthesis of fluorescent DNA primers for use in DNA sequence analysis. Nucleic Acids Res. 13: 2399-2412.

31. Mansfield, E.S., J.M. Robert son, R.V. Lebo, M.Y. Lucero, E.P. Mayrand, E. Rappaport, T. Parrella, S. Surrey, and P. Fortina. 1993. Duchenne/Becker muscular dystrophy carrier detection using quantitative PCR and fluorescence-based strategies. (in prep.).

32. Rye, H.S., S. Yue, D.E. Wemmer, M.A. Quesada, R.P. Haugland, R.A. Mathies, and A.N. Glazer. 1992. Stable fluorescent complexes of double-stranded DNA with bis-intercalating asymmetric cyanine dyes: Properties and applications. Nucleic Acids Res. 20: 2803-2812.

Received March 26, 1993; accepted in revised form June 25, 1993. 


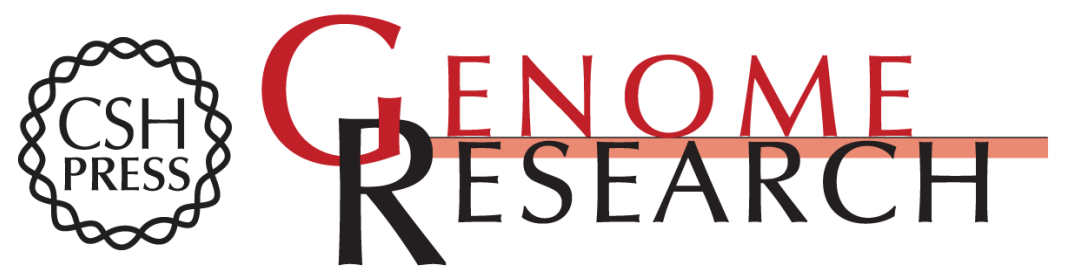

\section{Fluorescence-based RT PCR analysis: determination of the ratio of soluble to membrane-bound forms of Fc gamma RIIA transcripts in hematopoietic cell lines.}

M A Keller, D L Cassel, E F Rappaport, et al.

Genome Res. 1993 3: 32-38

References This article cites 31 articles, 6 of which can be accessed free at:

http://genome.cshlp.org/content/3/1/32.full.html\#ref-list-1

License

Email Alerting Receive free email alerts when new articles cite this article - sign up in the box at the Service top right corner of the article or click here.

\section{Affordable, Accurate} Sequencing.

To subscribe to Genome Research go to:

https://genome.cshlp.org/subscriptions 